\title{
組成傾斜構造と $\mathrm{Ar}$ 圧が $\mathrm{ZrN} / \mathrm{Zr} / \mathrm{ZrO}_{2}$ と $\mathrm{ZrN} / \mathrm{ZrO}_{2}$ 膜の硬さ及び付着力に与える影響
}

\author{
一山 正則* ·沢平 嘉浩* . 黒田 靖信*. 佐藤 彰繁* . 北河 勝* \\ 菊地 直人* $*$ 草野 英二* $\cdot$ 南戸 秀化 $*$. 金原 粲*
}

（受理1998年12月 2 日，掲載決定1999年 1 月 9 日）

Hardness and Adhesion Strength Enhancement by Compositional

Gradient Structure and Optimization of Ar Partial Pressure for $\mathrm{ZrN} / \mathrm{Zr} / \mathrm{ZrO}_{2}$ and $\mathrm{ZrN} / \mathrm{ZrO}_{2}$ Films Deposited by Reactive Sputtering Masanori ICHIYAMA*, Yosihiro SAWAHIRA*, Yasunobu KURODA*, Masaru KITAGAWA*, Naoto KIKUTI* Eiji KUSANO*, Hidehito NANTO* and Akira KINBARA*

(AMSRC, Kanazawa Institute of Technology, 3-1 Yatsukaho, Matsutou, Ishikawa 924-0838, Japan)

(Received December 2, 1998, Accepted January 9, 1999)

Effects of compositionally gradient structure and discharge gas pressure on microhardness and adhesion of $\mathrm{ZrN} / \mathrm{Zr}$ / $\mathrm{ZrO}_{2} /$ substrate and $\mathrm{ZrN} / \mathrm{ZrO}_{2} /$ substrate films have been studied. The apparatus used to deposit the films was an UHV-type sputtering machine with a $\mathrm{Zr}$ magnetron cathode. The compositional graduation of the films was formed by changing reactive gas flow rate gradually for a constant discharge current in the reactive sputtering. For film prepared, microhardness and adhesion strength were examined. The highest hardness was achieved for a $\mathrm{ZrN} / \mathrm{ZrO}$ film with a gradient interlayer deposited at an Ar partial pressure of $0.4 \mathrm{~Pa}$. The $\mathrm{ZrN} / \mathrm{ZrO}_{2}$ or $\mathrm{ZrN} / \mathrm{Zr} / \mathrm{ZrO}_{2}$ films with interrupted interfaces showed lower microhardnesses compared to the films with gradient interfaces. Although the adhesion strength increased as Ar partial pressure increased, the microhardness decreased. Thus, it was concluded from the experimental results obtained that the $\mathrm{ZrN} / \mathrm{ZrO}_{2}$ films with gradient interfaces deposited at a low Ar pressure yielded a high performance as a hard coating.

\section{1. 序論}

$\mathrm{ZrN}$ は，切削工具などのハードコーティングに主に 用いられている TiNよりも硬く1)，ハードューティング 材料乞して有望である. しかし，内部応力が大きく基板 から剥離しやすいため, その研究はあまりなされてい ない. 我々は, 剥離の対策として基板と膜との付着力を 高めるために, 酸化物を下地膜とし, 膜と膜の界面部分

\footnotetext{
* 金沢工業大学 AMSRC（宁924-0838 石川県松任市八束穗 3-1)
}

の組成を連続的に変化させた組成傾斜構造を持つ $\mathrm{ZrN}-$ $\mathrm{Zr}-\mathrm{ZrO}_{2}$ 多層薄膜を作製し, $\mathrm{Ti}$ 系多層薄膜よりも硬さ, 付着力ともに優れていることを報告した2).

しかし，ハードューティングに拈いて重要である硬さ 才るよび付着力に影響があると思われる薄膜の微細構造や 内部応力については, 報告していない。 また, 基板と異 なる材料を膜に用いると膜の格子が歪んで膜成長し，凹 凸で結晶性が悪い膜となるが，バッファー層として同じ 結晶材料を用いることにより格子歪みは小さくなり，平 坦で結晶性に優れた膜を得ることができる ${ }^{3)}$ た，最表 
面の $\mathrm{ZrN}$ ，下地膜とした $\mathrm{ZrO}_{2}$ と同じ結晶材料である $\mathrm{Zr}$ をバッファー層としたが, 硬さと付着力にどう影響 しているのかについての検討も不十分である.

そこで, 今回我々は, 組成傾斜構造を持つ $\mathrm{Zr}$ 系多層 薄膜の最適化を図るために, (1)薄膜の構造や内部応力に 強く影響を与えると考光られる放電ガス圧 ${ }^{4)} ，(2)$ バッフ アー効果を期待して中間層とした $\mathrm{Zr}$ の必要性を検討す るために積層構造を変数として, 組成傾斜構造を持つ $\mathrm{Zr}$ 系多層薄膜の硬さ及び付着力について検討した。

\section{2. 実験}

\section{1 成膜方法}

試料薄膜は, アネルバ(侏製の $\mathrm{dc}$ マグネトロンスパッ タリング装置（SPC-350UHV）を用いて成膜した。タ ーゲットには, (侏高純度化学研究所製の直径 $76.2 \mathrm{~mm}$, 純度 $99.9 \%$ （Hfを含む）の Zrを使用した。ターゲット 一基板間距離は， $54 \mathrm{~mm}$ とした．放電ガスには， $\mathrm{Ar}$ （純 度 $99.9999 \%$ 以上)を使用した. 反応性ガスには， $\mathrm{N}_{2}$ (純 度 $99.9999 \%$ 以上）と $\mathrm{O}_{2}$ （純度 $99.99 \%$ 以上）を使用し た，各ガスの流量は日本アェラ(侏製の FC-770型マスフ ローコントローラーで制御した．到達圧力は， $5 \times 10^{-5}$ $\mathrm{Pa}$ 以下とした. Ar 流量を $37.0 \mathrm{SCCM}$ とし, その圧力 を0.4〜1.6 Pa となるようにポンプの排気速度を調節し， 所定の反応性ガスを導入した，放電は，定電流モードで 行い, 電流值は $0.3 \mathrm{~A}$ とした. 基板にはアルミノ珪酸ガ ラス $(50 \mathrm{~mm} \times 50 \mathrm{~mm} \times 1 \mathrm{~mm})$ を用いた．内部応力の 片持ち梁法による測定ではホウ珪酸ガラス $(50 \mathrm{~mm} \times 10$ $\mathrm{mm} \times 0.21 \mathrm{~mm}$ ）を用いた. 成膜時の基板温度は， $200^{\circ} \mathrm{C}$ とした.

Fig. 1 亿一例として組成傾斜構造を持つ $\mathrm{ZrN}-\mathrm{Zr}$ $\mathrm{ZrO}_{2}$ 多層薄膜成膜時の反応性ガス流量の変化を示した. 基板と膜との付着力を高めるために反応性ガスとして最 初に酸素を用い，流量を $5 \mathrm{SCCM}$ と $2875 \mathrm{~s}$ 間流して $\mathrm{ZrO}_{2}$ 膜を成膜した。 バッファー効果を期待して, 反応 性ガスを流さずに $76 \mathrm{~s}$ 間， $\mathrm{Zr}$ 膜を成膜した。硬さに優 れた $\mathrm{ZrN}$ 膜は, 窒素流量を $5 \mathrm{SCCM} て ゙ 621 \mathrm{~s}$ 間流して 最表面に成膜した。膜と膜との界面での剥離を防ぐため に，酸素流量及び窒素流量をそれぞれ 5 0 SCCM，0～ 5 SCCM まで連続的に変化させ, 膜の組成を単調的に 傾斜させて成膜した．Fig. 2 亿，このときの試料薄膜の 断面の模式図を示した。試料薄膜の膜厚は，下層の $\mathrm{Zr}$ あるいは $\mathrm{ZrO}_{2}$ 及び組成傾斜中の膜厚は $100 \mathrm{~nm}$, 表面の $\mathrm{ZrN}$ が300 nm とした。な拉, 試料薄膜名の「一」は組 成傾斜有り「「/」は組成傾斜無しをそれぞれ示す。

\section{2 評価方法}

薄膜の微小硬さの測定には, (鍀エリオニクス製の超微

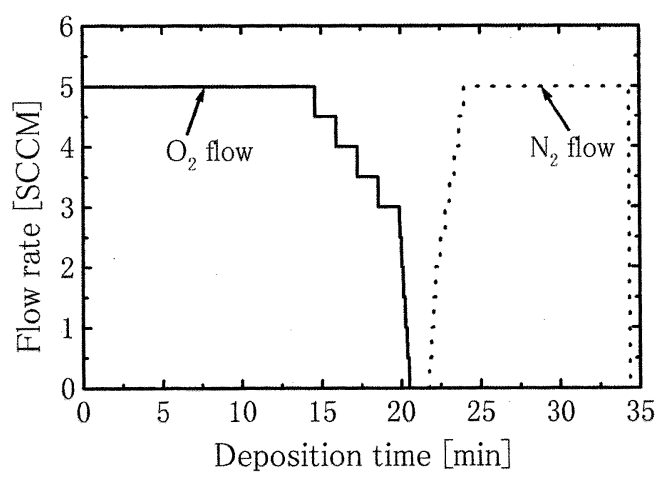

Fig. $1 \mathrm{O}_{2}$ and $\mathrm{N}_{2}$ flow rate as a function of deposition time during dc magnetron sputtering for $\mathrm{ZrN}-\mathrm{Zr}-$ $\mathrm{ZrO}_{2}$ multilayer film.

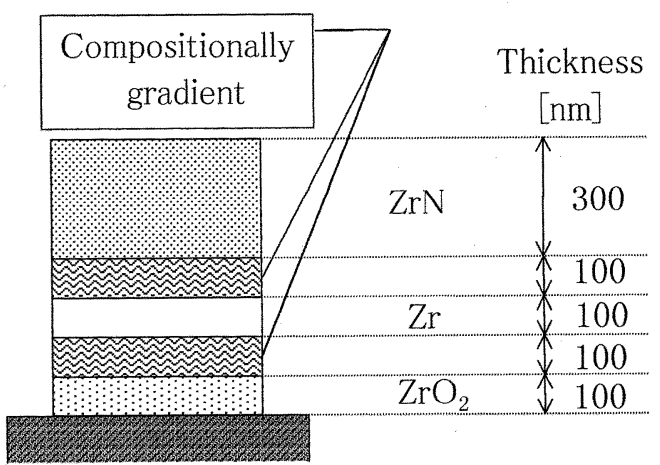

Substrate

Fig. 2 Schematic drawing of structure for $\mathrm{ZrN}-\mathrm{Zr}$ $\mathrm{ZrO}_{2}$ multilayer films.

小押し込反硬さ試験機（ENT-1040）を用い，圧子には ダイヤモンド三角錐圧子（稜間角 $115^{\circ}$ ) を用いた。試験 荷重は, $2.94 \mathrm{mN}$, 試験荷重保持時間を $1.0 \mathrm{~s}$ とし, 10 回 の連続自動測定を行った。そして，上下それぞれ 2 点を 除いた 6 点の平均をその試料の硬さとし，6 点の標準偏 差を誤差とした。ここで述べる硬さ $\mathrm{H}$ は, 最大荷重 $\mathrm{F}$ と圧子の最大押し込久深さ（最大变位）d 抢よび圧子の 形状定数 $\mathrm{k}(\mathrm{k}=37.838)$ から,

$$
\mathrm{H}=\mathrm{k} \frac{\mathrm{F}}{\mathrm{d}^{2}}
$$

として算出した.

薄膜の内部応力は, 片持ち梁法拉よび $\mathrm{ZrN}(200)$ 面の 格子歪みから算出した。片持ち梁法とは, 短冊形をした 薄い基板の一端を固定して薄膜を蒸着し，そのたわみの 量から内部応力を

$$
\sigma=\frac{E b^{2}}{3(1-v) 1^{2} \mathrm{~d}} \delta
$$




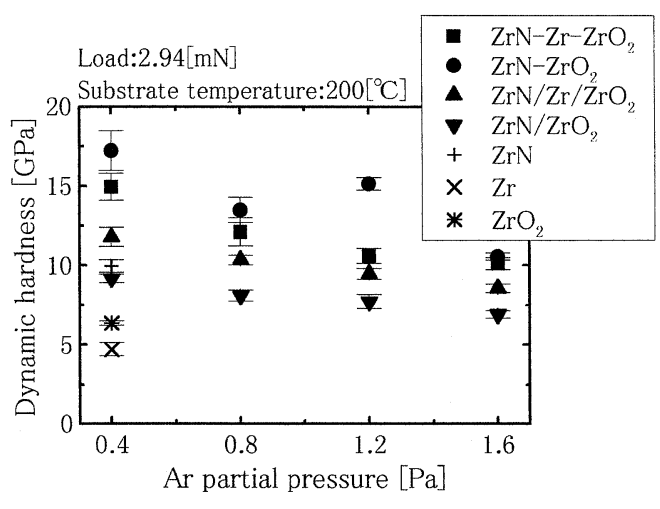

Fig. 3 Dynamic hardness of various multilayer films as a function of Ar partial pressure.

により算出する方法5)である。ここで， E は基板のヤン グ率, $\mathrm{b}$ は基板の厚さ, $v$ は基板のポアソン比, $\mathrm{d}$ は薄 膜の厚さ，1は基板の長さ， $\delta$ は薄膜を蒸着したとさの 基板の変位である.この片持ち梁法に用いた基板（ホウ 珪酸ガラス）のヤング率，ポアソン比は，それぞれ72.9 $\mathrm{mN} / \mathrm{m}^{2}, 0.208$ である.

格子歪みから内部応力を算出する方法とは, 薄膜内の 結晶に応力が働き, 結晶格子に歪みが生じて格子定数が 変化することを利用して，

$$
\sigma=\frac{\mathrm{E}}{2 v} \frac{\mathrm{d}_{0}-\mathrm{d}}{\mathrm{d}_{0}}
$$

により求める方法6である。ここで， $\mathrm{E}$ は作製した膜の ヤング率，vはポアソン比で本実験では測定不能のため 0.3一定とした。 また $\mathrm{d}_{0}$ は，昰みのない状態での格子間 隔であり，本実験では，JCPDS カードの值（0.2287 $\left.\mathrm{nm}^{7)}\right)$ とし，dは，作製した膜をX線回折により測定 した面間隔である。

付着力測定には，(株レスカのスクラッチ試験機 （CSR-02）を用いた。この試験機は，微小振幅による 表面の摩擦係数の変化からその臨界荷重を求め付着性の 強度を測定するものである ${ }^{8)}$. ここで述べる付着力は, 膜が基板からはがれたときの臨界荷重である、試験には 先端半径が $15.0 \pm 2 \mu \mathrm{m}$, センサー弾性係数 $260.0 \mathrm{gf} / \mathrm{mm}$ のダイヤモンド圧子を用い，ステージ傾斜角を $5.00^{\circ}$ ス テージ送りを $11.0 \mu \mathrm{m} / \mathrm{s}$, センサー励振振幅を $80 \mu \mathrm{m}$ と した.

\section{3. 結果および考察}

\section{1 硬さへの影響}

Fig. 3 に硬さ測定の結果を示す. Ar 分圧を増加する ことにより硬さは, 小さくなった。これは, 成膜時の

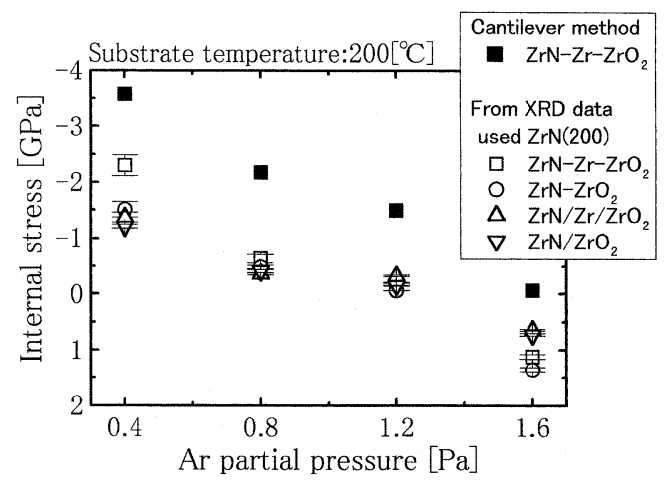

Fig. 4 Internal stress of various multilayer films as a function of Ar partial pressure.

$\operatorname{Ar}$ 分圧が高い場合に, 空隙や孔などの欠陷が多く, 密 度の低い膜が得られるといら良く知られた傾向 ${ }^{3)}$ と一致 している.

また，組成傾斜構造を持つ $\mathrm{ZrN}-\mathrm{Zr}-\mathrm{ZrO}_{2}$ 多層薄膜か ら $\mathrm{ZrN}-\mathrm{ZrO}_{2}$ 多層薄膜に積層構造を変えることにより 硬さは向上した．これは，中間層にある $\mathrm{Zr}$ が $\mathrm{ZrN} よ り$ も軟らかいためその影響が現れたと考えられる。

\section{2 内部応力への影響}

Fig. 4 に内部応力測定の結果を示した. 縦軸は内部応 力, 横軸は $\mathrm{Ar}$ 分圧をそれぞれ示した. 綎軸の負の值は 圧縮応力, 正の值は引張り応力をそれぞれ示している. 黒塗りのプロットは片持ら梁法により算出した, 組成傾 斜構造を持つ $\mathrm{ZrN}-\mathrm{Zr}-\mathrm{ZrO}_{2}$ 多層薄膜の内部応力を示し た. 他の多層薄膜の応力については, 片持ら梁法で測定 していないため $\mathrm{ZrN}(200)$ 面の格子歪みから算出した内 部応力を白抜きのプロットでそれぞれ示した。

$\operatorname{Ar}$ 分圧の増加により内部応力は減少した. Ar 分圧の 増加は, 薄膜内への $\mathrm{Ar}$ 分子のトラップを減少させ, 内 部応力を圧縮から引張りに変化させる効果を持つ9). ま た， $\mathrm{Ar}$ 分圧の増加は，薄膜の柱状構造化を促進するた め, 隣接するカラム間で引力が働き, 引張り応力になる 効果9) 子考光られる. これらの原因により内部応力は減 少したと考えられる.

一方，片持ち梁法と格子歪みから算出した内部応力の 違いは，(1)片持ち梁法が膜厚すべてについて内部応力を 算出しているのに対して，格子歪みから算出した方法 は，最表面の $\mathrm{ZrN}$ だけについて内部応力を算出してい ること，(2)薄膜のポアソン比を測定できなかったため 0.3一定としたことなどが考学られる．前者については， 格子歪みの測定結果が最表面の $\mathrm{ZrN}$ で引張り応力, 下 地膜 $\left(\mathrm{Zr}, \mathrm{ZrO}_{2}\right)$ で圧縮応力であったことから, 内部応 


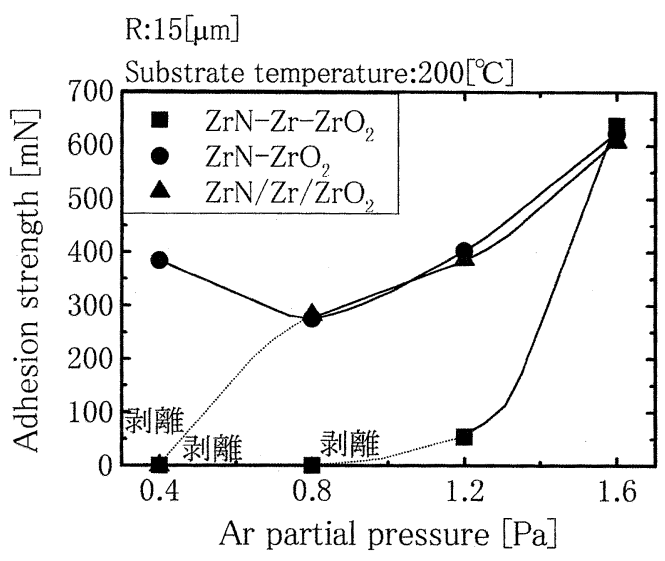

Fig. 5 Adhesion strength of various multilayer films as a function of Ar partial pressure.

力の挙動の違いからも説明できる.

$\mathrm{ZrN}(200)$ 面の格子歪夕から求めた内部応力は, 積層 構造の違いによる影響が見られなかった。

\section{3 付着力への影響}

Fig. 5 飞，付着力測定の結果を示した. Ar 分圧 0.4 $\mathrm{Pa}$ で成膜された $\mathrm{ZrN}-\mathrm{Zr}-\mathrm{ZrO}_{2}, \mathrm{ZrN} / \mathrm{Zr} / \mathrm{ZrO}_{2}$ 及び $\mathrm{Ar}$ 分圧 $0.8 \mathrm{~Pa}$ で成膜された $\mathrm{ZrN}-\mathrm{Zr}-\mathrm{ZrO}_{2}$ の付着力は, 膜 の自然剥離のため測定できなかった。

$\mathrm{Ar}$ 分圧を増加することにより今回検討した $\mathrm{Zr}$ 系多層 薄膜に执いて付着力は向上した。これは，Ar分圧を高 くすることにより薄膜の内部応力が減少している結果と 矛盾しない。

また，積層構造の違いにより全ての多層薄膜において 剥離が見られなかった組成傾斜構造を持つ $\mathrm{ZrN}-\mathrm{ZrO}_{2}$ 多層薄膜が最も付着力に優れていると考えられる.

\section{4 付着力と硬さの関係}

Fig. 6 亿硬さと付着力の関係を示した. 縦軸は硬さ, 横軸は付着力をそれぞれ示した. プロットの形と種類に より積層構造及び $\mathrm{Ar}$ 分圧をとれぞれ示している。

このグラフで右上にある程, 硬さと付着力ともに優れ た膜であることがいえる、したがって，全ての Ar 分圧 に执いて最も右上に位置する組成傾斜構造を持つ $\mathrm{ZrN}$ $\mathrm{ZrO}_{2}$ 多層薄膜が最もハードコーティング材料として優 れていると考朰れる。

\section{4. 結 論}

放電ガス圧, 拈よび積層構造を変数として組成傾斜構 造を持つ $\mathrm{Zr}$ 系多層薄膜を作製し, 硬さ及び付着力に与 劣る影響を検討した。その結果, 以下の結論を得た。

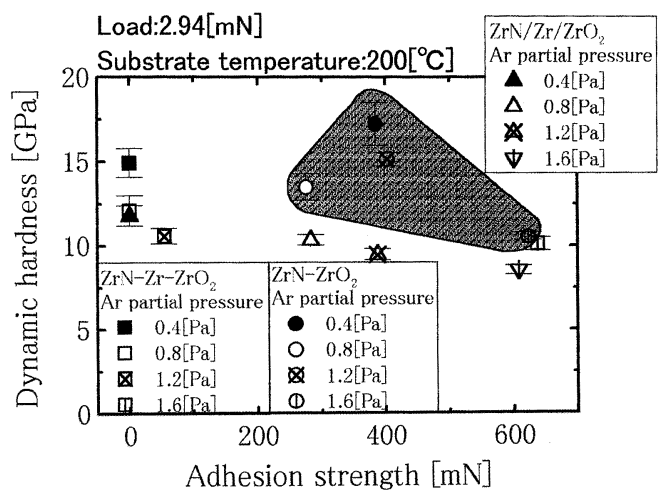

Fig. 6 Relationship between dynamic hardness and adhesion strength at various multilayer films.

・ Ar 分圧を増加することにより硬さ，内部応力は減少 するが，付着力は向上した.

・積層構造の違いにより, 内部応力は変化しないが, 硬 さ, 付着力ともに, 組成傾斜構造を持つ $\mathrm{ZrN}-\mathrm{ZrO}_{2}$ 多層薄膜が最も優れていた.

・バッファー効果を期待して中間層とした Zrは，硬 さ，付着力ともに減少させた。

以上のことから, 今回検討した 4 種類の $\mathrm{Zr}$ 系多層薄 膜に扣いては, 組成傾斜構造を持つ $\mathrm{ZrN}-\mathrm{ZrO}_{2}$ 多層薄 膜が硬さ，付着力ともに最も優れていた。

\section{謝辞}

本研究の一部は私立大学八イテク・リサーチ・センタ 一整備事業に対する助成により佂こなわれた。

\section{[文献]}

1) P. Panjan: Thin Solid Films, 228 (1993), P233-237. 2）黒田靖信，北河 勝，佐藤彰繁，草野英二，金原 粲：真空, vol. 41 No.3 (1998), P111.

3) (侏)応用物理学会 薄膜・表面物理分科会編: 薄膜作 製ハンドブック，共立出版株式会社，1991，P66-69.

4）小林春洋: スパッ夕薄膜基礎と応用, 日刊工業新聞 社, 1993, P61-64.

5）金原 粲：応用物理学選書 3 薄膜, 1979, P130131.

6）西田典秀編：表面技術, vol. 40 No. 6 (1989), P753.

7） JCPDS カードリスト, カード番号311493

8）関 継雄，竹下 䐙: 薄膜の密着性評価試験に関す る共同研究報告，(侏レスカ 開発グループ，1992，61993, 3, P9.

9）小林春洋 : スパッタ薄膜基礎と応用，日刊工業新聞 社, 1993, P65-71. 